\title{
Clinical Analysis of Auricular Benign Masses
}

\author{
Su Young Jung ${ }^{1}$, Myung Gu Kim², Sung Hyun Boo², Eun Kyung $\mathrm{Yeo}^{3}$, \\ Chul Kwon', Sun Kyu Lee ${ }^{1}$ and Seung Geun Yeo ${ }^{1}$ \\ 'Department of Otorhinolaryngology, School of Medicine, Kyung Hee University, Seoul, \\ 2Department of Otorhinolaryngology Head and Neck Surgery, Samsung Changwon Hospital, \\ Sungkyunkwan University School of Medicine, Changwon, \\ ${ }^{3}$ Department of Metal Jewelry Design, Sookmyung Women's University, Seoul, Korea
}

\begin{abstract}
Received November 7, 2011
Revised January 17, 2012

Accepted January 20, 2012
\end{abstract}

Background and Objectives: Auricular masses are growths on the outer ear that have not been well characterized clinically. We assessed the clinical nature and treatment of auricular benign masses in patients at our institution. Subjects and Methods: We retrospectively identified 63 patients with auricular benign masses who underwent excision and biopsy from May 1970 to April 2011. We determined the site, cause, size, pathology and postoperative results of these auricular masses. Results: Auricular benign masses occurred most commonly on the lobule (44.4\%), followed by the tragus (20.6\%), crus of helix (11.1\%), triangular fossa (6.3\%), crus of antihelix-antitragus (3.1\%) and scapha (1.5\%). Pathologically, the most common type of auricular mass was epidermal cysts (25.3\%), followed by hypertrophic scar (12.6\%), fibrous tissue-accessory ear (9.5\%), chronic inflammation-nevus (7.9\%), keloid (6.3\%), hemangioma (4.7\%), and skin tag-seborrheic keratosis (3.1\%). Conclusions: The most common site of auricular benign masses is the lobule and most common pathology is an epidermal cyst.

Korean J Audiol 2012;16:10-13

KEY WORDS: Auricular mass · External ear mass

\section{Introduction}

The auricle, which is the part of the ear exposed to the outside, is important both functionally and esthetically. ${ }^{1-3)}$ The skin of the auricle has little subcutaneous tissue, with the anterior surface having less subcutaneous tissue than the posterior surface, as well as being closely attached to the cartilage. These structures are subject to frostbite, despite the presence of a relatively abundant superficial blood supply. Moreover, auricular hematoma, which compresses the sensory nerves, can result in pain in response to mild inflammation. There are many clinical conditions that can occur in the auricle region, for instance, auricular anomaly, laceration, frostbite, otohematoma, perichondritis, herpeszoster otiticus and, occasionally, auricular masses. Auricular tumors, including basal cell carcinoma, squamous cell carcinoma, malignant melanoma and metastatic lesions have been assessed clinically, ${ }^{4)}$ mostly in case reports. However, there is little detailed information on auricular masses in general, such as keloids, osteomas and hemangiomas. To ad- dress this shortcoming, we retrospectively assessed the clinical characteristics of auricular masses in 63 patients, including their site, size, causes, histopathology, treatment methods and treatment results.

\section{Subjects and Methods}

We retrospectively identified 63 patients who visited the Department of Otorhinolaryngology from May 1970 to November 2009, were diagnosed with auricular masses and underwent mass excision. We assessed the site, cause, size, pathology results, treatment methods and treatment results in these patients. Site was assorted as the lobule, tragus, concha, crus of helix, triangular fossa, crus of antihelix, antihelix, antitragus, scapha and others. In patients who showed auricular mass recurrence after treatment, we assessed the interval from removal to recurrence, as well as the pathology, site and pattern of change in size. 


\section{Results}

\section{Site of auricular mass}

Of the 65 patients, $30(47.6 \%)$ were male and $33(52.3 \%)$ were female. Patients ranged in age from 1-80 years (mean, 33.5 years). 33 patients $(52.3 \%$ ) developed auricular masses in the right ear, $27(42.8 \%)$ in the left ear and $3(4.7 \%)$ in both ears. The most common site was the lobule $(\mathrm{n}=28,44.4 \%)$, followed by the tragus $(n=13,20.6 \%)$, crus of the helix $(n=7$, $11.1 \%)$, triangular fossa $(\mathrm{n}=4,6.3 \%)$, crus of the antihelix ( $\mathrm{n}=$ $2,3.1 \%)$, antitragus $(n=2,3.1 \%)$, scapha $(n=1,1.5 \%)$ and others $(n=6,9.5 \%)$ (Table 1$)$.

\section{Causes}

Of the 63 patients, $49(77.7 \%)$ had auricular masses of un-

Table 1. Ear sites of auricular masses and their biopsy results

\begin{tabular}{|c|c|c|c|}
\hline Site & $\mathrm{n}(\%)$ & Biopsy result & $n(\%)$ \\
\hline \multirow[t]{7}{*}{ Lobule } & $28(44.4)$ & Epidermal cyst & $11(17.4)$ \\
\hline & & Hypertrophic scar & $5(7.9)$ \\
\hline & & Chronic inflammation & $4(6.3)$ \\
\hline & & Fibrous tissue & $3(4.7)$ \\
\hline & & Keloid & $3(4.7)$ \\
\hline & & Hemangioma & $1(1.5)$ \\
\hline & & Skin tag & $1(1.5)$ \\
\hline \multirow[t]{5}{*}{ Tragus } & $13(20.6)$ & Accessory ear & $6(9.5)$ \\
\hline & & Nevus & $3(4.7)$ \\
\hline & & Fibrous tissue & $2(3.1)$ \\
\hline & & Epidermal cyst & $1(1.5)$ \\
\hline & & Skin tag & $1(1.5)$ \\
\hline \multirow[t]{7}{*}{ Crus of helix } & $7(11.1)$ & Epidermal cyst & $1(1.5)$ \\
\hline & & Chronic inflammation & $1(1.5)$ \\
\hline & & Hypertrophic scar & $1(1.5)$ \\
\hline & & Keloid & $1(1.5)$ \\
\hline & & Pyogenic granuloma & $1(1.5)$ \\
\hline & & Relapsing polychondritis & $1(1.5)$ \\
\hline & & Skin tag & $1(1.5)$ \\
\hline \multirow[t]{4}{*}{ Triangular fossa } & $4(6.3)$ & Epidermal cyst & $1(1.5)$ \\
\hline & & Hypertrophic scar & $1(1.5)$ \\
\hline & & Hemangioma & $1(1.5)$ \\
\hline & & Leiomyoma & $1(1.5)$ \\
\hline \multirow[t]{2}{*}{ Crus of antihelix } & $2(3.1)$ & Hemangioma & $1(1.5)$ \\
\hline & & Seborrheic keratosis & $1(1.5)$ \\
\hline \multirow[t]{2}{*}{ Antitragus } & $2(3.1)$ & Nevus & $1(1.5)$ \\
\hline & & Seborrheic keratosis & $1(1.5)$ \\
\hline Scapha & $1(1.5)$ & Nevus & $1(1.5)$ \\
\hline \multirow[t]{5}{*}{ Others } & $6(9.5)$ & Epidermal cyst & $2(3.1)$ \\
\hline & & Fibrous tissue & $1(1.5)$ \\
\hline & & Hypertrophic scar & $1(1.5)$ \\
\hline & & Lymph node & $1(1.5)$ \\
\hline & & Pilomatricoma & $1(1.5)$ \\
\hline
\end{tabular}

known origin, whereas the causes were congenital in 8 patients $(12.6 \%)$ and trauma in $6(9.5 \%)$ (Table 2).

\section{Size and pathology}

The masses had a mean \pm SD width of $15.4 \pm 4.32 \mathrm{~mm}$, a mean \pm SD height of $12.9 \pm 7.65 \mathrm{~mm}$ and a mean \pm SD depth of $10.2 \pm 7.01 \mathrm{~mm}$. Of the 63 biopsied masses, $16(25.3 \%)$ were epidermal cysts, 8 (12.6) were hypertrophic scar, 6 (9.5\%) were accessory ear, $6(9.5 \%)$ were fibrous tissue, five each (7.9\%) were chronic inflammation and nevus, 4 (6.3\%) were keloid, $3(4.7 \%)$ were hemangioma, 2 (3.1\%) each were seborrheic keratosis and skin tag and one each (1\%) was leiomyoma, pilomatricoma, relapsing polychondritis, pyogenic granuloma and lymph node (Table 3).

\section{Treatment results}

Among 63 cases of auricular mass, 62 were treated with a simple excision. One case of hypertrophic scar was treated with biopsy and local steroid injection and one case of relapsing polychondritis was treated with biopsy, local steroid injection and systemic steroid. The one case in which a simple excision was not enough with a keloid patient. In this case, a local skin flap was needed in addition to the excision. Following treatment, four patients (6\%; one male and three females) experienced recurrence. Pathology examination showed that the masses in three of these patients were hypertrophic scars

Table 2. Etiology of auricular masses

\begin{tabular}{lr}
\hline \multicolumn{1}{c}{ Etiology } & $\mathrm{n}(\%)$ \\
\hline Trauma & $6(9.5)$ \\
Congenital & $8(12.6)$ \\
Unknown origin & $49(77.7)$ \\
\hline
\end{tabular}

Table 3. Biopsy results of total auricular masses

\begin{tabular}{lc}
\hline \multicolumn{1}{c}{ Biopsy result } & $\mathrm{n}(\%)$ \\
\hline Epidermal cyst & $16(25.3)$ \\
Hypertrophic scar & $8(12.6)$ \\
Fibrous tissue & $6(9.5)$ \\
Accessory ear & $6(9.5)$ \\
Chronic inflammation & $5(7.9)$ \\
Nevus & $5(7.9)$ \\
Keloid & $4(6.3)$ \\
Hemangioma & $3(4.7)$ \\
Skin tag & $2(3.1)$ \\
Seborrheic keratosis & $2(3.1)$ \\
Pyogenic grauloma & $1(1.5)$ \\
Relapsing polychondritis & $1(1.5)$ \\
Leiomyoma & $1(1.5)$ \\
Lymph node & $1(1.5)$ \\
Pilomatricoma & $1(1.5)$ \\
\hline
\end{tabular}


Table 4. Characteristics and biopsy results of recurrent auricular masses

\begin{tabular}{cccccc}
\hline Patient number & Sex & Age & Site & Biopsy results & $\begin{array}{c}\text { Interval to recurrence } \\
\text { (months) }\end{array}$ \\
\hline 1 & M & 54 & Lobule & Epidermal cyst & 20 \\
2 & F & 53 & Lobule & Hypertrophic scar & 120 \\
3 & F & 40 & Triangular Fossa & Hypertrophic scar & 21 \\
4 & F & 25 & Crura of helix & Hypertrophic scar & 21 \\
\hline
\end{tabular}

and one was an epidermal cyst. Recurrence was observed in the lobule in two patients, and in the crus of the helix and the triangular fossa in one each. The mean interval to recurrence was 45.5 months. The average width, height and depth were $30 \mathrm{~mm}, 27 \mathrm{~mm}$ and $17 \mathrm{~mm}$, respectively, prior to recurrence, and $19 \mathrm{~mm}, 17 \mathrm{~mm}$ and $10 \mathrm{~mm}$, respectively, after recurrence (Table 4).

\section{Discussion}

The auricle is a complex skeletal system formed by thin and fine skin tissues, such that many types of techniques and approaches are used to treat auricular masses. It is important to understand the diagnosis prior to surgery or clinical treatment. Many auricular masses, however, are difficult to diagnose by physical examination and fine needle aspiration, ${ }^{5)}$ with most requiring diagnosis by biopsy after surgical excision. Moreover, there have been few reports on auricle masses, making it difficult to obtain information. We therefore investigated the clinical aspects of auricular masses in 65 patients who underwent auricular surgery over the past 41 years.

The ear lobule was the most common site of auricular masses, followed by the tragus, crus of the helix, triangular fossa, concha-crus of the antihelix and antitragus-scapha. Frequent development in the lobule may be related to its being the area of the auricle with the greatest abundance of soft tissue, as well as due to the wearing of earrings and other jewelry, which may induce scars or inflammation.

Pathologically, epidermal cyst was the most common manifestation. These cysts have been reported in the posterior surface of the lobule, mastoid skin, inferior area of the cartilagenous external auditory canal (EAC) and posterior skin. Epidermal cysts manifest as soft, non-tender masses and, when accompanied by inflammation, are difficult to distinguish from otofuruncles. ${ }^{6}$ Cysts must be excised completely and dissected carefully during surgery so not to rupture the cystic wall.

Eight patients had hypertrophic scars and five had keloids. Hypertrophic scars rarely recur after surgical excision, and some degenerate spontaneously. In contrast, the recurrence rate of keloid treated by surgery only is high (45-100\%), making it important to differentiate keloids from hypertrophic scars in deciding treatment methods. Generally, keloids show a pattern of infiltration beyond primary scars, whereas hypertrophic scars are limited. ${ }^{7,8)}$ In addition, hypertrophic scars form within 4 weeks after injury, whereas keloids form later, an average of 30.4 months after injury. ${ }^{9,10)}$ Moreover, hypertrophic scars decrease in size within 1 year, whereas keloids maintain their size for longer than 1 year. ${ }^{11)}$ Hypertrophic scars are treated by surgery only, whereas keloids are treated by surgery followed by local injection of steroids, which decreases the expression of genes encoding collagen. ${ }^{12)}$

Due to their recurrence, long-term follow-up in patients with keloids is important. The average interval to recurrence has been reported to range from 5.5-12.9 months, ${ }^{13)}$ suggesting that patients be followed-up for longer than 1 year. Of our three patients with keloid recurrence, two were at 21 months and one at 10 years, suggesting the need for even longer follow-up.

Hemangiomas, observed in three of our patients, are congenital tumors observed most commonly in infants and usually involves the face and neck together with the auricle. Hemangiomas can be classified into several types. Capillary hemangiomas are masses composed of large capillary vessels without severe large protrusions, with large blood vessels supplying the blood in the center, from which capillary vessels branch and form a port-wine stain or spider hemangiectasia. Cavernous hemangiomas are composed of endothelial cells, are filled with blood and appear as protrusions or masses. ${ }^{14)}$ These tumors cause problems in appearance. In most patients, these masses not treated until they show a maximum decrease in size, after which they are treated by cryotherapy, radiotherapy, electrotherapy, sclerosing therapy, tattooing and other methods. ${ }^{15)}$

Basal cell carcinomas, observed in two of our patients, constitute approximately $20 \%$ of the tumors occurring in the EAC and temporal bone. These skin cancers are relatively common, especially in elderly individuals, and are more prevalent in males than in females. Despite being malignant histologically, these tumors show a benign progression, with metastasis being very rare. In most cases, these tumors are painless and nodular, with an ulcerative central area. ${ }^{16)}$ Although most do not show distinct borders of subcutaneous infiltration, the borders of these tumors are grossly distinct, the tumors grow 
slowly and distant and local metastases are rare. Among the methods used to treat basal cell carcinoma are surgical excision, curettage, electrotherapy, radiotherapy, cryotherapy, laser therapy, chemical therapy, local application of cytotoxic agents and intralesion injection. Treatments are chosen after considering functional aspects and cosmetic efficacy, together with complete removal of the lesion, based on patient clinical characteristics, including the extent of infiltration, histological lesion type, patient sex and age, reactions to previous treatment methods and remission rate. ${ }^{17)}$ Both of our patients with basal cell carcinoma underwent surgical excision, with no recurrences for up to 2 years after surgery.

Only one of our patients was diagnosed with perichondritis, which, nevertheless, should be diagnosed differentially from basal cell carcinoma. Two patients had keratosis, which requires differential diagnosis from squamous cell carcinoma. Hence, patients with masses expected to be benign should undergo physical examination and biopsy of the lesion. ${ }^{18)}$

\section{Conclusion}

Although auricular masses are frequently encountered in outpatient clinics, few studies have investigated these conditions. Hence, it is difficult to obtain information on these lesions and to design treatment plans. We found that most of the masses in the auricle were benign tumors, requiring appropriate surgery only, with good treatment outcomes and without recurrence. In rare cases, some auricular masses may be malignant tumors, requiring close observation and optimal treatment methods.

\section{REFERENCES}

1) Grant DA, Finley ML, Coers CR 3rd. Early management of the burned ear. Plast Reconstr Surg 1969;44:161-6.

2) Purdue GF, Hunt JL. Chondritis of the burned ear: a preventable complication. Am J Surg 1986;152:257-9.

3) Kim JK, Eom DS, Jang EK, Kim YB, Cho CS, Yang KH, et al. A clinical evaluation of chondritis in the burned ear. Korean J Otolaryngol-Head Neck Surg 1992;35:717-22.

4) Bojanović M, Zivković-Marinkov E, Veselinović D, Bojanović A, Vucković I. [Malignant tumors of auricula and periauricular area]. Vojnosanit Pregl 2009;66:611-6.

5) Lee SH, Jun BC, Lee DH, Cho KJ. A case of enchondral pseudocyst of the auricle. Korean J Otorhinolaryngol-Head Neck Surg 2007;50: $713-5$.

6) Ozcan KM, Dere H, Ozcan I, Gun T, Unal T. An epidermal cyst in the parotid gland following ear surgery: a case report. B-ENT 2006; 2:193-5.

7) Urioste SS, Arndt KA, Dover JS. Keloids and hypertrophic scars: review and treatment strategies. Semin Cutan Med Surg 1999;18:159-71.

8) Muir IF. On the nature of keloid and hypertrophic scars. Br J Plast Surg 1990;43:61-9.

9) Niessen FB, Spauwen PH, Schalkwijk J, Kon M. On the nature of hypertrophic scars and keloids: a review. Plast Reconstr Surg 1999; 104:1435-58.

10) Cosman B, Crikelair GF, Ju DMC, Gaulin JC, Lattes R. The surgical treatment of keloids. Plast Reconsr Surg 1961;27:335-58.

11) Larrabee WF Jr, East CA, Jaffe HS, Stephenson C, Peterson KE. Intralesional interferon gamma treatment for keloids and hypertrophic scars. Arch Otolaryngol Head Neck Surg 1990;116:1159-62.

12) Griffith BH, Monroe CW, McKinney P. A follow-up study on the treatment of keloids with triamicinolone acetonide. Plast Reconstr Surg 1970;46:145-50.

13) Chowdri NA, Masarat M, Mattoo A, Darzi MA. Keloids and hypertrophic scars: results with intraoperative and serial postoperative corticosteroid injection therapy. Aust N Z J Surg 1999;69:655-9.

14) Covelli E, De Seta E, Zardo F, De Seta D, Filipo R. Cavernous haemangioma of external ear canal. J Laryngol Otol 2008;122:e19.

15) Ol'shanskiǐ MS, Korotkikh NG, Shcherbinin AS, Stepanov IV. [Combined treatment of auricular vascular neoplasms]. Vestn Otorinolaringol 2008:48-50.

16) Ahmad I, Das Gupta AR. Epidemiology of basal cell carcinoma and squamous cell carcinoma of the pinna. J Laryngol Otol 2001;115:85-6.

17) Albright SD 3rd. Treatment of skin cancer using multiple modalities. J Am Acad Dermatol 1982;7:143-71.

18) Bridges MN, Doval M. Cutaneous squamous cell carcinoma of the external auditory canal. Dermatol Online J 2009;15:13. 